\title{
Legalisasi Bentuk Kelompok Usaha Untuk Peningkatan Produksi Olahan Bambu di Dusun Koloh Brora Desa Menggala Kabupaten Lombok Utara
}

\author{
Baiq Nurul Suryawati*, Laila Wardani, Muttaqillah \\ Jurusan Manajemen, Fakultas Ekonomi dan Bisnis, Universitas Mataram \\ *Corresponding Author: bnurulsuryawati@gmail.com
}

\begin{abstract}
The purpose of this service is to help business owners choose the right form of business, besides that, with the existence of business legalization, it can support home businesses to develop themselves and survive in business situations that are full of uncertainty. The method of implementing community service is carried out by providing assistance where information is provided regarding business legalization and the requirements that need to be prepared to obtain legalization, besides watching watching together is carried out as part of learning by looking at examples of other successful businesses. The community service participants are all young people who are included in the bamboo craftsmen group in Koloh Berora Hamlet. The business legalization chosen by the business owner is $\mathrm{CV}$, the business legalization arrangement is carried out in the City of Mataram, because the bureaucracy in North Lombok has not been able to properly facilitate the legalization of the business. The craftsmen group put up signs as an effort to market their products, in line with the directions that have been given.
\end{abstract}

Abstrak: Tujuan pengabdian ini adalah untuk membantu pemilik usaha memilih bentuk usaha yang tepat, selain itu dengan adanya legalisasi usaha dapat mendukung usaha rumahan untuk mengembangkan diri dan bertahan dalam situasi bisnis yang penuh ketidak-pastian. Metode pelaksanaan pengabdian dilakukan dengan melakukan pendampingan dimana informasi diberikan terkait legalisasi usaha dan persyaratan yang perlu dipersiapkan untuk memperoleh legalisasi, selain itu kegiatan nonton bareng dilakukan sebagai bagian pembelajaran dengan melihat contoh usaha lain yang sudah sukses. Peserta pengabdian adalah seluruh pemuda yang termasuk dalam kelompok pengrajin bambu di Dusun Koloh Berora. Hasil dari kegiatan pengabdian ini adalah adanya legalisasi usaha yang dipilih oleh pemilik usaha, yaitu CV, pengurusan legalisasi usaha dilakukan di Kota Mataram. Kelompok pengrajin memasang plang sebagai upaya memasarkan produk mereka, sejalan dengan arahan yang telah diberikan, selain itu kelompok pengrajin melakukan fokus pada upaya memasarkan diri, dengan mendirikan plang nama di gerbang artshop mereka

How to Cite: Suryawati, B., Wardani, L., \& Muttaqillah, M. (2021). Legalisasi Bentuk Kelompok Usaha Untuk Peningkatan Produksi Olahan Bambu di Dusun Koloh Brora Desa Menggala Kabupaten Lombok Utara. Jurnal Pengabdian UNDIKMA, 2(1), 73-82. doi:https://doi.org/10.33394/jpu.v2i1.3282

doi:https://doi.org/10.33394/jpu.v2i1.3282

This is an open-access article under the CC-BY-SA License.

\section{Article History:}

Received: 23-12-2020

Reviewed: 06-02-2021

Accepted: 03-04-2021

Published: 05-05-2021

\section{Key Words:}

Business

Legalization,

Bamboo Processing,

Applications, Sales

Promotion.

\section{Sejarah Artikel:}

Diterima: 23-12-2020

Direview: 06-02-2021

Disetujui: 03-04-2021

Diterbitkan: 05-05-2021

\section{Kata Kunci:}

Legalisasi Usaha, Olahan

Bambu, Aplikasi,

Promosi Penjualan.

\section{Pendahuluan}

Sebagai salah satu tujuan wisata, keberadaan berbagai usaha yang bergerak di bidang pariwisata saat ini sangat erat kaitannya dengan perkembangan ekonomi nasional. Industri ini umumnya merupakan industri yang terkait dengan kepariwisataan seperti adanya desa wisata, usaha kuliner berbasis ciri khas daerah, pusat suvenir khas lokal, dimana usaha ini mempunyai kedudukan, potensi dan peranan yang sangat penting dalam mewujudkan tujuan 
pembangunan ekonomi. Berbagai jenis usaha di industri pariwisata ini diharapkan mampu menciptakan atau memperluas kesempatan kerja, distribusi pendapatan dan meningkatkan pendapatan masyarakat serta mampu menciptakan stabilitas ekonomi (Rosyidie, n.d.).

Adanya kejadian bencana alam gempa bumi, di tahun 2018 menyebabkan berbagai daerah khususnya Kabupaten Lombok Utara, menunjukkan kondisi perekonomian yang belum membaik sepenuhnya. Optimisme tetap dibangun untuk menghadapi mundurnya industri pariwisata saat ini yang menjadi sumber utama ekonomi masyarakat. Oleh karena banyaknya sektor ekonomi rakyat yang berbasis pada pengembangan industri pariwisata, baik hulu hingga hilir, maka pembinaan dan pengembangan industri pariwisata sudah selayaknya harus mendapat perhatian pemerintah dan swasta. Bentuk perhatian dapat diwujudkan dalam upaya pembinaan dan pengembangan seperti penyuluhan, pendidikan pelatihan, motivasi, konsultasi, pendampingan serta dalam bentuk lainnya yang mengarah pada perbaikan mutu usaha.

Lebih lanjut di Dusun Koloh Berora, Desa Menggala, Kecamatan Pemenang Barat, Kabupaten Lombok Utara menjanjikan berbagai macam potensi potensi usaha berbasis kepariwisataan. Hal ini didukung dengan banyak potensi alam yang dapat dikembangkan menjadi berbagai jenis usaha kreatif dan ramah lingkungan. Oleh karena adanya industri rumahan, yang kreatif dan ramah lingkungan memungkinkan banyak masyarakat untuk dapat terlibat di dalamnya. Akan tetapi, kenyataan di lapangan nampak berbanding terbalik, kecenderungan masyarakat, umumnya lebih suka membuka kios atau berjualan kelontong. Hal ini dilakukan karena dianggap mudah dan banyaknya penduduk yang menjalankan usaha yang sama. Sementara yang terlupakan adalah keberadaan usaha sejenis justru menimbulkan persaingan yang ketat dan keuntungan sulit didapat.

Data dari Dinas Koperasi NTB tahun 2019 menunjukkan bahwa untuk Kabupaten Lombok Utara, sentra kerajinan bambu berupa tusuk sate dan gigi, batok kelapa tercatat terdapat di Dusun Bangket Kecamatan Gangga. Saat ini, walaupun terdapat potensi Dusun Koloh Brora dapat diberdayakan agar mampu mengembangkan olahan bambu lainnya, para pemuda di Dusun Koloh Brora, mulai mengembangkan berbagai macam produk tersebut. Produk ini dihasilkan oleh penduduk lokal dan mulai diminati wisatawan. Permasalahan utama dari pengembangan industri bambu tidak lain adalah pada inovasi desain. Dibutuhkan kemampuan dan perlakuan khusus dalam pengolahan bambu. Pertumbuhan dan bentuk bambu tidak bisa dikendalikan oleh manusia. Sebagai contoh akan sulit mendapatkan ukuran dan bentuk bambu yang sama untuk dijadikan bahan kerajinan. Praktisi, pengusaha, dan pengrajin sudah berusaha namun belum secara optimal dan berkelanjutan. Memang perlu adanya campur tangan pemerintah untuk pengembangan industri bambu, pengendalian harga, dan pasar produk yang dihasilkan (Anonim, n.d.).

Sebagaimana dikutip diatas, peluang olahan bambu terbuka luas, terutama di Dusun Koloh Berora. Dusun ini terletak di wilayah sekitar pusuk dan merupakan daerah pariwisata, serta jalan masuk untuk eksplorasi wisata di kisaran Kabupaten Lombok Utara. Banyaknya lahan berbukit sangat berpotensi untuk pengembangan desa wisata. Tidak hanya pengembangan desa wisata, kondisi permukiman juga layak untuk dikembangkan menjadi area outbond dan rekreasi. Kesulitan yang dihadapi para penduduk adalah selain minimnya kreativitas, juga informasi terkait perijinan usaha dan rencana bisnis yang layak. Selama ini masyarakat sekitar hanya memiliki orientasi untuk memulai usaha sekedar sebagai mata pencaharian sambilan. Berkenaan dengan situasi tersebut, maka pendampingan ini akan dilakukan untuk membantu penduduk di dusun Koloh Brora untuk memiliki legal format terkait perijinan usaha dan rencana bisnis demi pengembangan usaha jangka panjang. 
Penduduk di Dusun Koloh Berora umumnya memiliki keterbatasan informasi, sehingga usaha yang mereka geluti tidak disiapkan untuk maju dengan memiliki ijin usaha yang sesuai dan rencana bisnis. Penduduk tidak memiliki pengetahuan untuk mengenali bagaimana potensi usaha dapat dikembangkan. Pengembangan usaha di Dusun Koloh Brora dilakukan dengan intuisi saja. Kreativitas dan kejelian masyarakat melihat peluang perlu dipetakan dalam sebuah studi dengan mengulas analisis Strength Weaknesses Opportunity and Threats (SWOT). Selain itu, penduduk umumnya langsung menutup usaha jika terjadi penurunan pembelian. Penduduk memiliki keengganan untuk mempertahankan usaha yang sudah dirintis. Minimnya pengenalan legalisasi usaha dan rencana bisnis yang mudah untuk diterapkan, menyebabkan banyak usaha dijalankan hanya berdasarkan intuisi saja. Usaha yang dijalankan umumnya hanya usaha dagang saja, usaha ini tidak memberikan kesempatan untuk menambah nilai produk. Keberlangsungan usaha dagang ini tidak menjanjikan. Penduduk perlu mengenali berbagai cara untuk meningkatkan keterampilan diri. Peningkatan keterampilan ini diharapkan dapat meningkatkan peluang untuk memulai usaha potensial untuk peningkatan pendapatan yang berkesinambungan. Efendi, et al (2020) melakukan pelatihan pengolahan jarum tiram berbasis entrepreneurship untuk dapat membantu para santri NW Kayangan Lombok Barat agar dapat membuka lapangan pekerjaan. Upaya ini dilakukan untuk meningkatkan life skill dari para santri dengan salah satu-nya melakukan demonstrasi mengolah jarum tiram yang memiliki potensi untuk dikembangkan.

Penduduk di dusun Koloh Brora dengan keterampilan olahan bambu, terkesan pasif karena hanya memproduksi tanpa terlebih dahulu mengenali potensi pasar yang tersedia. Apabila terjadi penurunan pendapatan maka penduduk akan segera menutup usaha tersebut, tanpa melakukan evaluasi pasar yang sudah terjadi. Pendampingan untuk membuat perijinan dan rencana usaha, menyasar pada dua poin: Pertama, yaitu pendampingan pembuatan ijin usaha. Tahapan ini akan mendatangkan pembicara yang dari dinas terkait. Fasilitator yaitu tim pengabdian masyarakat beserta mahasiswa KKN yang dialokasikan oleh LPPM (Lembaga Penelitian dan Pengabdian Kepada Masyarakat) diperlukan untuk memfasilitasi berbagai kegiatan hingga ijin usaha diperoleh. Kedua, berkenaan dengan pendampingan penyusunan Rencana Bisnis, tim fasilitator akan mendampingi penduduk dengan berbagai keterampilan untuk memasarkan produk. Keterampilan memasarkan produk dimulai dengan mengenali produk dan optimasi sosial media. Selain itu keterampilan penataan keuangan juga dilakukan agar penduduk dapat mengevaluasi usaha mereka.

Adapun tujuan dari program pengabdian kepada masyarakat ini adalah untuk mendampingi ijin usaha dan rencana bisnis bagi penduduk di Dusun Koloh Brora. Penduduk yang dimaksud sebagai target adalah para pemuda di dusun Koloh Brora-Kabupaten Lombok Utara yang mengikuti program pendampingan dan merupakan penduduk asli yang menjalankan usaha kreatif untuk meningkatkan taraf hidup mereka.

\section{Metode Pengabdian}

Metode yang digunakan dalam kegiatan pengabdian ini adalah pendampingan pembentukan usaha ini yang akan dirancang dengan secara intensif mendampingi kelompok pemuda yang memiliki keterampilan memulai usaha olahan bambu. Tim fasilitator juga akan mendampingi dalam memasarkan serta mengevaluasi hasil usaha agar target yaitu penduduk atau keompok pemuda tersebut dapat termotivasi untuk mengembangkan usaha mereka. Tim fasilitator pengabdian masyarakat merencanakan dan mengembangkan berbagai metode untuk rencana bisnis. Selanjutnya, diciptakan suasana yang menyenangkan agar target yaitu penduduk dan kelompok pemuda tersebut dapat memberikan informasi dan berpartisipasi 
secara lugas dengan membantu mereka memasarkan produk mereka. Beberapa metode ice breaking juga akan dilakukan untuk mengidentifikasi beragam informasi dari penduduk atau target yaitu kelompok pemuda, berkenaan dengan pengembangan keterampilan yang mereka miliki. Selain tim pengabdian, dengan koordinasi dari LPPM program pengabdian ini juga akan melibatkan mahasiswa KKN. Penempatan dan pengalokasian mahasiswa KKN serta penentuan Dosen Pembimbing Lapangan akan sepenuhnya dalam kewenangan LPPM.

\section{Hasil Pengabdian dan Pembahasan}

Kegiatan pengabdian dilakukan dengan melakukan wawancara pada para pemuda yang bekerja di workshop untuk menghasilkan produk olahan bambu. Berdasarkan hasil wawancara, penanggung-jawab produksi mengeluhkan sistem birokrasi yang harus dilalui untuk formalisasi usaha mereka. Selanjutnya dapat diobservasi, usaha tersebut secara rutin melakukan produksi, sembari melakukan produksi prose belajar dan peningkatan desain dilakukan. Untuk dapat memberikan informasi menyeluruh tentang materi pengabdian maka dilakukan tahapan berikutnya, yaitu acara nonton bareng sekaligus focus group discussion untuk bersama mengidentifikasi permasalahan yang ada untuk mencari solusi yang tersedia. Berikut adalah beberapa dokumentasi yang dilakukan saat program pengabdian masyarakat dilaksanakan:

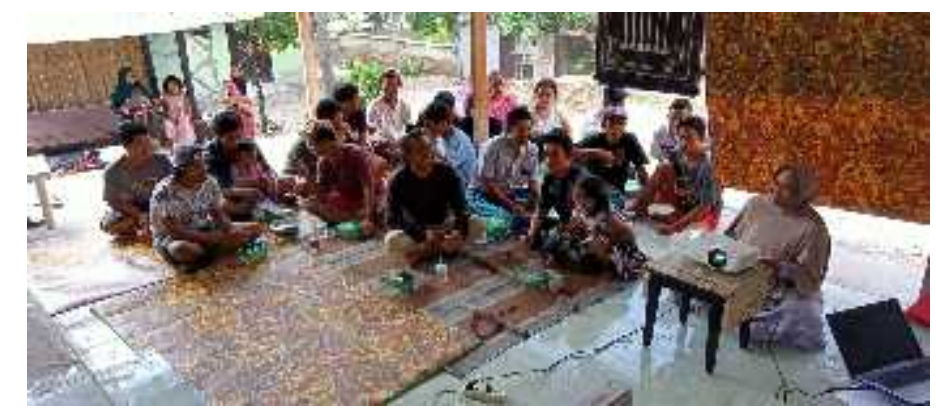

Gambar 1. Nonton Bareng dengan Pengrajin Olahan Bambu

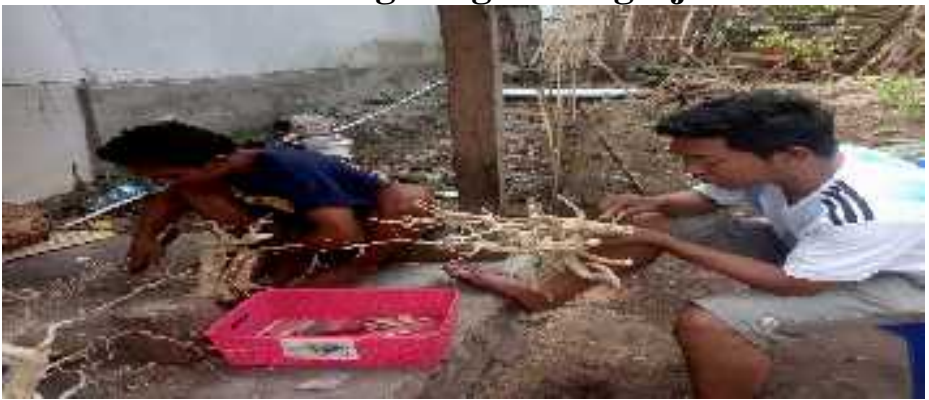

Gambar 2. Beberapa Pekerja Membuat Produk Olahan Akar Kayu ....

Beberapa materi yang diberikan saat focus group discussion adalah tentang pemasaran sektor informal. Sektor informal sebagai kegiatan ekonomi masyarakat kecil dengan modal kecil, memiliki sifat dan teknik usaha yang sederhana (non organisasi, non management dan non administrasi), menjadi bahasan sekaligus alternatif pemecahan masalah sosial-ekonomi, berawal pada semakin besarnya penawaran tenaga kerja akibat tingginya laju pertumbuhan penduduk yang dihadapkan pada kenyataan demand lapangan kerja yang sangat terbatas. Keadaan ini tidak hanya terjadi di perkotaan (sektor industri) karena alasan rendahnya skill, arus urbanisasi, alternatif mekanisasi, dan kapasitas produksi, tetapi juga di pedesaan (sektor agraris) yang ditandai suatu kenyataan semakin sempitnya lahan garapan pertanian (Rogers, 2003). 
Pembinaan dan bantuan perlu diberikan, mengingat sektor informal memiliki ciri-ciri yang sekaligus merupakan kelemahan sebagai berikut : 1) Pola kegiatannya tidak teratur, baik jam kerja maupun teknik usahanya. 2) Memiliki skala usaha kecil, teknologi sederhana dan tradisional. 3) Struktur usaha sering sebagai unit keluarga. 4) Umumnya hanya melayani golongan masyarakat ekonomi menengah ke bawah. 5) Tingkat pendidikan dan keterampilan tenaga kerja yang umumnya rendah. 6) Tidak/belum mengenal sistem perbankan, perkreditan dan pengelolaan usaha untuk melakukan/mengembangkan usahanya dengan baik. 7) Tidak/belum mampu mengaitkan usahanya dengan usaha yang lebih besar. 8) Sering kali pelaksanaan kegiatan usaha berdasar hubungan pribadi dan kepercayaan, bukan atas dasar hukum perjanjian formal.

Apapun kondisi dan bagaimanapun sektor informal melaksanakan aktivitasnya dengan berbagai kelemahan yang dimiliki, harus diakui bahwa sampai saat ini secara minimum sektor ini telah memberikan kontribusi untuk mengatasi masalah tenaga kerja/pengangguran dan sumber pendapatan masyarakat.

Dalam komunikasi lebih diarahkan pada usaha-usaha untuk merubah pengetahuan, sedang pada difusi lebih memusatkan pada terjadinya perubahan tingkah laku yang tampak, yaitu menolak atau menerima terhadap ide/gagasan baru. Sedangkan unsur-unsur difusi adalah : 1) Inovasi, 2) Komunikasi melalui saluran tertentu, 3) Dalam jangka waktu tertentu, 4) Anggota suatu sistem sosial yang ada. Inovasi adalah gagasan, ide, tindakan atau barang yang dianggap baru oleh seseorang. Rogers (2003) mengungkapkan : Inovation is an idea, practice, or object percieved as new by individual or other unit of adoption. Sifat baru inovasi tersebut diukur secara nyata dan subyektif menurut pandangan individu yang menerimanya.

Marketing Mix merupakan bentuk inovasi yang perlu diadopsi oleh setiap pelaku usaha dalam bidang/jenis apapun baik dalam kapasitas besar/ menengah ataupun kecil, termasuk sektor informal. Pada sektor informal, marketing mix adalah sesuatu yang perlu benar-benar diketahui dan dipahami untuk diterapkan pada usaha yang dilakukan. Hal ini penting artinya mengingat kelemahan mendasar pada sektor ini adalah dalam pengambilan keputusan pemasaran. Jones \& Healey (1993) (Kotler, Armstrong, Eizaguirre, \& GarcíaFeijoo, 2018) menegaskan bahwa pengambilan keputusan dalam pemasaran disebut catur tunggal pemasaran (marketing mix) yakni : Produk, Harga, Saluran Distribusi, dan Promosi.

Keputusan/kebijakan pelaku usaha dalam hal produk, harus memperhatikan tentang produk apa yang harus diproduksi, bagaimana produk harus dikerjakan, bagaimana produk tersebut harus dirancang atau didisain, bagaimana produk harus dikemas dan jasa apa yang harus melengkapi produk tersebut serta mengenal dan memperhatikan selera pasar. Harga, merupakan unsur yang serius dalam pemasaran. Tinggi rendahnya harga produk yang dihasilkan harus dengan cermat memperhatikan daya beli konsumen, biaya produksi yang telah dikeluarkan dan kepercayaan konsumen terhadap kualitas produk. Dalam persaingan, harga tidak selalu menjadi pilihan utama (daya pikat) konsumen. Pembeli mempunyai estimasi korelatif antara harga dengan kualitas barang. Harga barang yang terlalu murah sering tidak menjadi pilihan pembeli atas barang tersebut. Sebaliknya hanya menitik beratkan kualitas produk dan mengabaikan daya beli konsumen, kurang signifikan terhadap omzet penjualan. Hendaknya penetapan harga dilakukan dengan memperhitungkan dengan cermat segala biaya produksi dan keuntungan yang diharapkan, serta ukuran daya beli konsumen (share market), sehingga usaha mampu berkembang dengan baik.

Jarak antara produsen dan konsumen, harus dipertimbangkan pada tingkat efisiensi dan efektifitas serta keuntungan dalam menetapkan saluran distribusi pemasaran (antara lain : 
wholesaler, grosir, retailer, pengecer). Pemasaran yang menggunakan perantara berarti produsen mempercayakan usahanya kepada perantara terhadap produk untuk sampai di tangan konsumen. Produsen tidak dapat mengetahui secara langsung pendapat/tanggapan konsumen terhadap produk yang dihasilkan. Akan tetapi produsen memiliki lebih banyak waktu untuk mengembang kegiatan usaha yang dilaksanakan. Kondisi tersebut akan terjadi sebaliknya jika pemasaran dilakukan sendiri oleh produsen. Dalam kaitan ini Kotler (1985) mengungkapkan/membandingkan bagaimana suatu distribusi mempengaruhi penghematan usaha.

Promosi, sebagai bagian dari unsur marketing mix ini pada dasarnya merupakan saluran tersendiri. Menurut Kotler, Armstrong, Eizaguirre, \& García-Feijoo (2018) kegiatan promosi dikenal sebagai promotion mix, yang meliputi sarana periklanan, promosi penjualan, penjualan pribadi dan publisitas. Penetapan sarana promosi tersebut harus dikoordinasikan secara efektif pada sasaran komunikasi dengan cermat kepada konsumen (pelanggan/calon bembeli baru), dengan memperhatikan kekuatan perusahaan dan pesaing usaha. Unsur ini menjadi sangat penting sebagai usaha memperkenalkan produk, meletakkan landasan persuasif hingga mengarahkan calon pembeli menjatuhkan pilihan untuk membeli/memiliki tanpa keraguan terhadap produk yang dihasilkan. Promosi yang lazim dipergunakan dalam berbagai bentuk sarana promosi antara lain adalah memberikan sampel (contoh produk), menyebarkan kupon belanja, mengemas penjualan dalam paket harga, memberikan potongan harga khusus dan seterusnya. Selanjutnya, Kotler, Armstrong, Eizaguirre, \& García-Feijoo, (2018) memberikan gambaran arti penting relatif dari sarana promosi, sebagai berikut Promotion mix, dipengaruhi oleh produsen dalam menetapkan strategi penjualan, yaitu 1) Strategi dorong (push strategy), dimana produsen secara agresif mempromosikan produk kepada saluran distribusinya (mulai grosir sampai dengan pengecer) hingga konsumen semakin tertarik/percaya bahkan jika perlu menanamkan pure monopoli atas produk yang dihasilkan. 2) Strategi tarik (pull strategy), dalam hal ini produsen mempromosikan produk secara langsung kepada konsumen. Keberhasilan promosi ini membuat konsumen menanyakan produk tersebut kepada pengecer, selanjutnya pengecer menanyakan kepada grosir dan seterusnya, hingga saluran ini berjalan dan menambah omzet penjualan. Sebagai suatu inovasi, cepat lambatnya suatu inovasi (marketing mix) dapat diserap oleh pelaku usaha di sektor informal, menurut Rogers (2003), sangat tergantung dari atribut inovasi itu sendiri, yaitu : 1) Relative advantage is the degree to which an innovation is percieved as better than idea it supersedes. 2) Compatability is the degree to which an innovations is percieved as consistent with existing values, past experiences, and needs of potential adopters. 3) Complexity is the degree to which an innovation is perceivedas relative difficult to understand and use. 4) Triability is the degree to which an innovations may be experimented with on limited basis. 5) Observability is the degree to which an innovation are visible to orthers.

Penerimaan atau penolakan inovasi marketing mix, sangat tergantung pada pelaku/pengusaha sektor informal. Jika ia menerima (mengadopsi) inovasi, dia akan mualai dengan ide-ide baru, dan menggantikan penggunaan ide yang terdahulu. Keputusan inovasi adalah proses mental, sejak ia mengetahui adanya inovasi sampai mengambil keputusan untuk menerima atau menolaknya kemudian mengukuhkannya.

Marketing mix merupakan suatu inovasi yang penting untuk diadopsi oleh sektor informal, terutama dalam mengatasi kendala utama di bidang pemasaran produk. Proses pengadopsian inovasi ini akan dapat berjalan dengan baik melalui kelompok-kelompok usaha yang ada baik dalam bentuk Koperasi Pengusaha Kecil, Asosiasi Pengusaha Kecil dan 
kelompok lain yang menghimpun keberadaan sektor informal. Kelompok usaha ini sebagai media difusi inovasi marketing mix yang efektif, karena kelompok usaha berfungsi sebagai forum/media tukar informasi. Keberadaannya tercermin pada saat diadakannya acara tatap muka dalam pertemuan yang telah dijadwalkan secara rutin. Dalam acara semacam itu, kelompok usaha merupakan forum yang produktif untuk saling bertukar fikiran dan pengalaman usaha sesama anggota. Kemungkinan untuk memberi dan menerima berbagai masukan yang berkaitan dengan usaha, akan dapat berlangsung secara alamiah. Adanya heterogenitas permasalahan masalah di antara anggota secara langsung akan menyebabkan heterogenitas sikap yang dimiliki, merupakan bahan yang menarik untuk dibicarakan sekaligus didiskusikan. Dengan demikian kelompok usaha ini mempunyai daya tarik yang kuat untuk mengarahkan anggota (pelaku usaha) kepada tujuan dalam rangka pengadopsian marketing mix sebagai suatu inovasi.

Fungsi lain dari kelompok usaha sektor informal adalah sebagai media pembentuk sikap. Hal ini didasarkan pada suatu aksioma bahwa tekanan kelompok secara intens menyebabkan perubahan-perubahan psikologis pada anggota kelompok. Dengan adanya perubahan psikologis tersebut pada akhirnya akan melahirkan sikap baru yang lebih positif dan konstruktif pada diri anggota kelompok, sesuai dengan pesan yang diberikan oleh pembina atau nara sumber lain tentang penerapan marketing mix. Dalam kaitan ini, kelompok usaha sektor informal sebagai media komunikasi dan pembentukan sikap, perlu ditampilkan figur penyampai inovasi yang mampu dan terpercaya, dengan strategi penyampaian yang tidak bertentangan dengan kehendak dan kemampuan anggota serta tantangan yang dihadapi.

Selain materi marketing mix, disampaikan juga materi tentang pentingnya pembentukan kelompok usaha. Pembangunan di Indonesia yang dilaksanakan secara berkesinambungan bertujuan untuk meningkatkan kesejahteraan rakyat Indonesia secara adil dan merata. Hasil dari pembangunan yang dilaksanakan secara bertahap diharapkan dapat memperbaiki kondisi kehidupan masyarakat, baik pada tatanan sosial ekonomi maupun budaya namun demikian hasil kegiatan pembangunan belum dapat menghilangkan masalah kemiskinan secara menyeluruh. Hal ini dapat dibuktikan dengan cukup tingginya angka kemiskinan di Indonesia yaitu 14 persen pada yang juga mengakibatkan Penyandang Masalah Kesejahteraan Sosial (PMKS) di Indonesia masih tinggi. Menurut data, indeks kedalaman dan keparahan kemiskinan di desa lebih besar dibandingkan di kota, hal ini menunjukkan bahwa penanganan kemiskinan di daerah pedesaan harus lebih intensif. Pentingnya menempatkan masyarakat sebagai pelaku utama dalam pembangunan di Indonesia menunjukkan perubahan paradigma pembangunan dari pendekatan pertumbuhan (growth approach) kepada pendekatan kemandirian (self-reliance approach). Ada lima paradigma yang mendasari proses pelaksanaan pembangunan di suatu negara, yaitu pertumbuhan, welfare state, neo ekonomi, structuralize dan humanizing. Kelima paradigma ini hanya bergerak pada tiga dimensi yaitu: pertumbuhan, kesejahteraan, dan people centered. Dengan demikian dapat disimpulkan bahwa pendekatan ini menempatkan manusia sebagai subyek pembangunan dan menekankan pada pentingnya pemberdayaan (empowerment) manusia. Oleh karena itu, Kementerian Sosial menerapkan beberapa program penguatan ekonomi kerakyatan dengan strategi mendorong kemandirian usaha-usaha kelompok masyarakat, disamping itu juga sebagai salah satu upaya penanggulangan kemiskinan. Wujud kegiatan ini adalah pengembangan Kelompok Usaha Bersama (KUBE) yang merupakan program asistensi kesejahteraan sosial keluarga. Sedangkan dalam perkembangannya Kementerian Sosial melalui Dirjen Pemberdayaan Sosial mengeluarkan program Bantuan Langsung Pemberdayaan Sosial (BLPS) sebagai tindak lanjut dari program KUBE ini, dimana program ini ditujukan unuk 
KUBE tumbuh yang pernah di bentuk atau diberdayakan oleh dinas sosial provinsi maupun kabupaten atau kota. Memperkuat potensi atau daya yang dimiliki oleh masyarakat (empowering). Dalam rangka ini diperlukan langkah-langkah lebih positif selain dari hanya menciptakan iklim atau suasana. Memberdayakan mengandung pula arti melindungi. Dalam proses pemberdayan harus dicegah yang lemah menjadi bertambah lemah kerena kurang berdaya dalam menghadapi yang kuat.

Materi pemberdayaan masyarakat, diuraikan untuk melengkapi materi lainnya. Pemberdayaan merupakan usaha memberi sebagian daya atau kekuasaan (power-sharing) kepada kelompok yang dianggap kurang berdaya. Pemberian daya tersebut diharapkan akan memberi lebih banyak kesempatan kepada suatu kelompok tertentu untuk berkembang dengan memanfaatkan potensi yang ada dalam dirinya maupun peluang yang tumbuh di luar kelompok (Adimiharja dan Hikmat, 2004 dalam Ariffudin, 2009). Dilihat dari proses operasionalisasi, maka ide pemberdayaan memiliki dua kecenderungan (Bappenas, 2003). Pertama kecenderungan primer, yaitu kecenderungan proses yang memberikan atau mengalihkan sebagian kekuasaan, kekuatan, atau kemampuan kepada masyarakat atau individu menjadi lebih berdaya, dan kecenderungan sekunder, yaitu kecenderungan yang menekankan pada proses memberikan stimulasi, mendorong, atau memotivasi individu agar mempunyai kemampuan atau keberdayaan untuk menentukan apa yang menjadi pilihan hidupnya melalui proses dialog. Pemberdayaan mengacu kepada pentingnya proses sosial selama program berlangsung. Jadi, lebih berorientasi pada proses, bukan kepada hasil. Tujuan filosofis-nya adalah untuk memberikan motivasi atau dorongan kepada masyarakat dan individu agar menggali potensi yang ada pada dirinya untuk ditingkatkan kualitasnya, sehingga akhirnya mampu mandiri. Terlihat bahwa proses pembelajaran dan adanya proses menuju pembuatan perubahan yang permanen merupakan kunci utama dalam pemberdayaan. Kemiskinan bukan merupakan permasalahan ekonomis semata (rendahnya pendapatan dan produktivitas kerja), melainkan juga merupakan permasalahan sosial yang kompleks, sehingga memerlukan pendekatan komprehensif dan terpadu yang melibatkan berbagai pihak terkait. Karena itu pendekatan dalam menelaah dan menangani kemiskinan sangat tepat jika dipengaruhi oleh perspektif pekerjaan sosial (social work) (Suharto, 2003).

Pendekatan Kelompok Usaha Bersama (KUBE) yang dilandasi pertimbangan akan kenyataan berbagai keterbatasan yang melekat pada perorangan Penyandang Masalah Kesejahteraan Sosial (PMKS). Penanganan secara kelompok dimaksudkan juga guna menumbuh-kembangkan semangat kebersamaan dalam upaya peningkatan taraf kesejahteraan sosial melalui pelatihan keterampilan berusaha, pemberian bantuan stimulan sebagai modal kerja, dan pendampingan. Kegiatan pokok pembentukan KUBE untuk sasaran lainnya adalah sebagai berikut:

1) Pelatihan keterampilan berusaha, dimaksudkan untuk meningkatkan kemampuan praktis berusaha yang disesuaikan dengan minat dan ketrampilan serta kondisi wilayah, termasuk kemungkinan pemasaran dan pengembangan basil usahanya. Nilai tambah lain dari pelatihan adalah tumbuhnya rasa percaya diri dan harga diri untuk mengatasi permasalahan yang dihadapi dan memperbaiki kondisi kehidupannya;

2) Pemberian bantuan stimulan sebagai modal kerja atau berusaha yang disesuaikan dengan keterampilan dan kondisi setempat. Bantuan ini merupakan hibah (bukan pinjaman atau kredit) akan tetapi diharapkan bagi penerima bantuan untuk mengembangkan dan menggulirkan kepada warga masyarakat lain yang perlu dibantu; 
3) Pendampingan, mempunyai peran sangat penting bagi berhasil dan berkembangnya KUBE, mengingat sebagian besar merupakan kelompok yang paling miskin dan penduduk miskin. Secara fungsional pendampingan dilaksanakan oleh Petugas Sosial yang dibantu oleh infrastruktur kesejahteraan sosial di daerah seperti Karang Taruna, Pekerja Sosial Masyarakat, Organisasi Sosial, dan Wanita Pemimpin Usaha

Kelompok Usaha Bersama (KUBE) adalah himpunan dari keluarga dengan keinginan dan kesepakatan bersama membentuk suatu wadah kegiatan, tubuh dan berkembang atas dasar prakarsa sendiri, saling berinteraksi antar satu dengan yang lain, dan tinggal dalam satu wilayah tertentu dengan tujuan untuk meningkatkan produktivitas anggotanya, meningkatkan relasi sosial yang harmonis, memenuhi kebutuhan anggota, memecahkan masalah sosial yang dialaminya dan menjadi wadah pengembangan usaha bersama. KUBE merupakan sarana untuk meningkatkan Usaha Ekonomis Produktif (khususnya dalam peningkatan pendapatan), memotivasi warga untuk lebih maju secara ekonomi dan sosial, meningkatkan interaksi dan kerjasama dalam kelompok, mendayagunakan potensi dan sumber sosial ekonomi lokal, memperkuat budaya kewirausahaan, mengembangkan akses pasar dan menjalin kemitraan sosial ekonomi dengan pihak terkait. Kegiatan usaha diberikan dalam bentuk pemberian bantuan modal usaha dan sarana prasarana ekonomi. Mewujudkan KUBE hendaknya diawali dengan pembentukan kelompok dari mereka oleh mereka dan untuk mereka. Satu kelompok KUBE dapat memilih anggota-nya yang mempunyai kemampuan serta potensi. Kelembagaan KUBE ditandai dengan: 1) Jumlah anggota KUBE, yang terdiri dari 5-10 KK; 2) Ikatan pemersatu, yaitu kedekatan tempat tinggal, jenis usaha atau keterampilan anggota, ketersediaan sumber, latar belakang kehidupan budaya, memiliki motivasi yang sama, keberadaan kelompok masyarakat yang sudah tumbuh berkembang lama; 3) Struktur dan kepengurusan KUBE, yang terdiri dari Ketua, Sekretaris, dan Bendahara. Bantuan Langsung Pemberdayaan Sosial (BLPS) adalah jenis program pemberdayaan Departemen Sosial yang menitik-beratkan pemberian atau penguatan modal usaha untuk KUBE yang telah dibina sebelumnya. Sumber dana BLPS berasal dari anggaran Pemerintah Pusat (melalui Depsos RI) dan Pemerintah Daerah. Berikut adalah beberapa dokumentasi kegiatan pengabdian masyarakat yang dilakukan di Dusun Koloh Brora.

\section{Kesimpulan}

Kesimpulan yang diperoleh dari hasil kegiatan pengabdian ini adalah kelompok pengrajin olahan bambu di Dusun Koloh Brora, Desa Menggala, Kabupaten Lombok Utara merespon program pengabdian dengan memilih betuk legalisasi usaha, yaitu $\mathrm{CV}$, selain itu kelompok pengrajin melakukan fokus pada upaya memasarkan diri, dengan mendirikan plang nama di gerbang artshop mereka.

\section{Saran}

Pemasaran yang masih konvensional yang dilakukan kelompok pengrajin bambu adalah dengan menambahkan plang, pemasaran ini dapat dimaksimalkan dengan pemasaran berbasis sosial media, program pengabdian selanjutnya akan mengoptimasi berbagai jenis pemasaran sosial media. Selain itu, dengan legalisasi usaha, kelompok pengrajin dapat mengajukan proposal permohonan pendanaan ke instansi terkait, optimasi alternatif pendanaan ini selanjutnya dapat disosialisasikan pula dalam program pengabdian lainnya. 


\section{Daftar Pustaka}

Anonim, A. (t.thn.). Diambil kembali dari https://www.pertanianku.com/potensi-bambusebagai-bisnis-sangat-menjanjikan/

Efendi, I., Safnowandi, S., Dewi, I., Utami, S., \& Abidin, Z. (2020). Pelatihan Produk Olahan Jamur Pasca Panen untuk Penguatan Produktivitas Ekonomi SMA Islam Al-Azhar NW Kayangan. Jurnal Pengabdian UNDIKMA, 1(2), 100-105. doi:https://doi.org/10.33394/jpu.v1i2.2876

Jones, M., \& Healey, J. (1993). Miracle Sales Guide. Prentice Hall.

Kotler, P., Armstrong, G., Eizaguirre, A., \& García-Feijoo, M. (2018). Marketing Mix: Selected Chapters From: Principles of Marketing. Pearson Publishing.

Rogers, E. (2003). Diffusion of Innovations. New York: Free Press.

Rosyidie, A. (t.thn.). Kelompok Keahlian Perencanaan Wilayah dan Perdesaan SAPPK ITB. Diambil kembali dari https://sappk.itb.ac.id/pwd_old/pwd/index.php/pub/np/111gunung-merapi 